Historic, Archive Document

Do not assume content reflects current scientific knowledge, policies, or practices. 



\section{Emlong's 1927 Price List}

Figure Prices Correctly The prices given below apply separately to each variety. For example, the each of two different varieties, the price will be $\$ 1.00$ for each variety. More than 500 plants of a variety sold at the 1000 rate.

\begin{tabular}{|c|c|c|c|c|c|}
\hline Column 1 & Column 2 & Column 3 & Column 4 & Column 5 & Column 6 \\
\hline $\begin{array}{l}\text { SEN. DUNLAP } \\
\text { GIBSON }\end{array}$ & $\begin{array}{c}\text { EATON } \\
\text { DR. BURRILL }\end{array}$ & $\begin{array}{l}\text { PREMIER } \\
\text { AROMA }\end{array}$ & $\begin{array}{l}\text { COOPER } \\
\text { PEARL }\end{array}$ & $\begin{array}{l}\text { CHAMPION } \\
\text { PROGRESSIVE }\end{array}$ & $\mathrm{DON}$ \\
\hline 0.25 & 0.30 & $25 \mathrm{Pla}$ & 25 Plar & $\$ \$ 0.75$ & 25 Pla \\
\hline .40 & .45 & lants & 50 Plants & 50 Plants 1.25 & 50 Plants 2.50 \\
\hline ants & .65 & lants & 75 Plants 1.05 & 75 Plants 1.65 & 75 Plants 3.25 \\
\hline ints & .85 & is 1.00 & ts $\mathbf{1 . 2 5}$ & ants 2.00 & ts 4.0 \\
\hline 1.05 & lants 1.25 & s 1.3 & ants 1. & ants 2 . & ts 5.7 \\
\hline lants 1.30 & lants 1.00 & lants 1.6 & Plants 2.00 & 200 Plants 3.20 & ts 7.50 \\
\hline lants 1.50 & 250 Plants 1.85 & Plants 1.90 & 250 Plants 2.45 & 250 Plants 3.80 & 250 Plants 9.00 \\
\hline ants 1.65 & lants 2.05 & lants 2. & Plants 2.75 & 300 Plants 4.35 & s 10.50 \\
\hline ts 1.8 & s 2.30 & & 3. & 5. & 1275 \\
\hline ts 2.00 & lants 2.50 & s 3. & $s \quad 4.00$ & ts 6.50 & 15.50 \\
\hline 1000 Plants 4.00 & Plants $\mathbf{5 . 0 0}$ & Plants $\mathbf{5 . 5 0}$ & 1000 Plants 8.00 & 1000 Plants 12.00 & 1000 Plants 30.00 \\
\hline
\end{tabular}

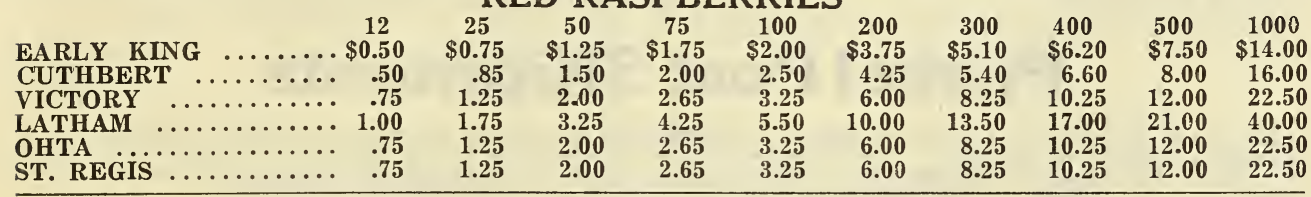

\section{BLACK RASPBERRIES}

\begin{tabular}{|c|c|c|c|c|c|c|c|c|c|c|}
\hline & 12 & 25 & 50 & 75 & 100 & 200 & 30.0 & 400 & 500 & 1000 \\
\hline CUMBERLAND & $\$ 0.75$ & $\$ 1.15$ & $\$ 2.00$ & $\$ 2.65$ & $\$ 3.00$ & $\$ 5.00$ & $\$ 6.75$ & $\$ 8.50$ & $\$ 9.50$ & $\$ 18.00$ \\
\hline PLUM FARMER .. & .75 & 1.15 & 2.00 & 2.65 & 3.00 & 5.00 & 6.75 & 8.50 & 9.50 & 18.00 \\
\hline WINFIELD $\ldots \ldots$ & .85 & 1.25 & 2.25 & 2.90 & 3.50 & 6.75 & 8.50 & 11.25 & 13.00 & 25.00 \\
\hline HONEY SWEET & 1.00 & 1.50 & 2.75 & 3.75 & 4.50 & 8.2 & 11.00 & 13.50 & 15.00 & 30.00 \\
\hline KANSAS & .75 & 1.15 & 2.00 & 2.65 & 3.00 & 5.00 & 6.75 & 8.50 & 9.50 & 18.00 \\
\hline COLUMBIAN & 1.00 & 1.50 & 2.75 & 3.75 & 4.50 & 8.25 & 11.00 & 13.50 & 15.00 & 30.00 \\
\hline
\end{tabular}

RASPBERRY TRANSPLANTS

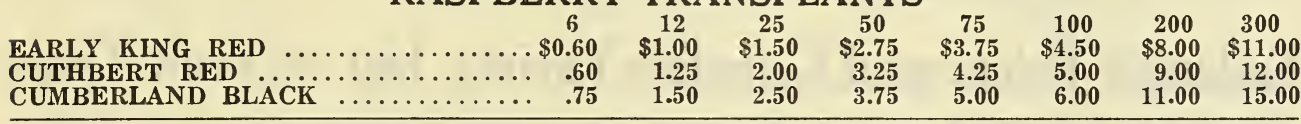

\section{BLACKBERRIES AND DEWBERRIES}

\begin{tabular}{|c|c|c|c|c|c|c|c|c|c|c|}
\hline Sucker Plants- & 12 & 25 & 50 & 75 & 100 & 200 & 300 & 400 & 500 & 1000 \\
\hline ELDORADO & $\$ 0.50$ & $\$ 0.85$ & $\$ 1.50$ & $\$ 2.00$ & $\$ 2.50$ & $\$ 4.25$ & $\$ 5.40$ & $\$ 7.00$ & $\$ 8.50$ & $\$ 16.00$ \\
\hline $\begin{array}{l}\text { MERSEREAU } \ldots \ldots \ldots \\
\text { Root Cutting Plants- }\end{array}$ & .75 & 1.15 & 2.00 & 2.60 & & 5.00 & 6.75 & 8 & 10 & \\
\hline ELDORADO & .75 & 1.15 & 2. & 2.60 & 3.00 & 5. & 6. & 8. & 1 & 0 \\
\hline MERSEREAU & .85 & 1.25 & 2. & 2.5 & 3. & 6.75 & 8. & 11.8 & 13.00 & 25.00 \\
\hline BLOWERS & .85 & 1.22 & 2. & 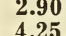 & & 6.75 & 8.50 & 11.2 & 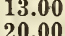 & 25.00 \\
\hline LUCRETIA DEWBERR & 1.0 & 1.1 & $\begin{array}{l}3.25 \\
2.00\end{array}$ & $\begin{array}{l}4.25 \\
2.65\end{array}$ & $\begin{array}{l}0.50 \\
3.00\end{array}-10$ & $\begin{array}{r}10.00 \\
5.00\end{array}$ & $\begin{array}{r}13.50 \\
6.75\end{array}$ & 8.50 & $\begin{array}{r}2.00 \\
9.00\end{array}$ & $\begin{array}{l}40.00 \\
18.00\end{array}$ \\
\hline
\end{tabular}

GRAPE VINES (325 or more at 1000 rate)

\begin{tabular}{|c|c|c|c|c|c|c|c|c|c|}
\hline & Each & 60 & 12 & 25 & 50 & 100 & 200 & 300 & 1000 \\
\hline CONCORD, 1-yr. XXX & $\$ 0.10$ & $\$ 0.50$ & $\$ 0.80$ & $\$ 1.35$ & $\$ 2.25$ & $\$ 4.00$ & $\$ 7.50$ & $\$ 9.00$ & $\$ 25.00$ \\
\hline $\begin{array}{l}\text { CONCORD, 2-yr. XXX } \\
\text { NIAGARA, 1-yr. XXX }\end{array}$ & $\begin{array}{l}.15 \\
.12\end{array}$ & $\begin{array}{l}.75 \\
.60\end{array}$ & $\begin{array}{l}1.20 \\
1.00\end{array}$ & $\begin{array}{l}2.00 \\
1.60\end{array}$ & $\begin{array}{l}3.50 \\
2.75\end{array}$ & $\begin{array}{l}6.00 \\
5.00\end{array}$ & $\begin{array}{r}11.00 \\
9.00\end{array}$ & $\begin{array}{l}15.00 \\
11.00\end{array}$ & $\begin{array}{l}40.00 \\
35.00\end{array}$ \\
\hline NIAGARA, 2-yr. XXX & .15 & .85 & 1.50 & 2.50 & 4.00 & 7.00 & 12.00 & 16.50 & 50.00 \\
\hline OORE'S EARLY, 1-yr. XXX & .12 & .60 & 1.00 & 1.60 & 2.75 & 5.00 & 9.00 & 11.00 & 35.00 \\
\hline OORE'S EARLY, 2-yr. XXX & 15 & .8 & 1. & 2.75 & 4. & 8. & 14 & 1 & 60.00 \\
\hline CAMPBELL'S EARLY, 1-yr. XX & 15 & 85 & 1.6 & 2. & 4.50 & 8.00 & 14.00 & 19.50 & 60.00 \\
\hline ORDEI & .12 & 60 & 1.0 & 1.60 & 2.75 & 5.00 & 9.00 & 11.00 & 35.0 \\
\hline DELAWARE, 1 -yr. XXX & .15 & 85 & 1.6 & 2.75 & 4.50 & 8.00 & 14.00 & 19.50 & 60.00 \\
\hline 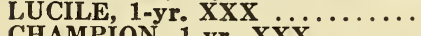 & .20 & 1.00 & 1.85 & 3.50 & 6.00 & 10.00 & & & \\
\hline 1 -yr. XXX & .10 & .50 & .90 & 1.50 & & & 9.00 & 1.00 & 35.00 \\
\hline
\end{tabular}

OUR GUARANTEE We guarantee that every plant, tree, shrub or vine described in this catalog is just antee that years experience makes this guarantee possible and gives you invaluable protection. condion. Fr. until you are; if any cause for complaint, write us inmediately-you will find us anxious to correct any error on our part. 


\section{Strawberries Pay Big Quick Profits $\$ 500.00$ to $\$ 1500.00$ Per Acre}

Why not plant an acre or more this Spring and get your share of this easy money. In order to encourage acre plantings we are making a special price of $\$ 25.00$ on 8,000 plants, enough for one acre.

\section{Strawberry Plants Only $\$ 25.00$}

\section{$1 / 4$ ACRE COLLECTION}

1000 Sen. Dunlap

1000 Gibson

$$
\text { ONLY } \$ 7.50
$$

\section{$1 / 2$ ACRE COLLECTION} Sen. Dunlap 2000 Gibson

\section{Sen. Dunlap}

4000 Gibson

ONLY $\$ 25.00$

IF YOU PREFER you may order two, four or eight thousand plants of either of the above varieties.

\section{The "Big Three" Strawberries}

\section{SPECIAL LOW PRICE DEMONSTRATION BLOCKS}

There never has been and probably never will be another trio of Strawberries that will equal Premier Early, Cooper Mid-season and Pearl Late as a money making combination. If we were planting 100 acres for fruiting it would be planted solid to these three great varieties and the new Mastodon. There is big money in Strawberries and by planting one of these demonstration blocks you are assured unusual profits. You will get the fancy prices always paid for extra early and extra late berries. Your berries will sell for a premium above all others-because all of your berries will be EXTRA FANCY.

\section{$\square$ 1/4 ACRE COLLECTION}

1000 Premier

500 Cooper

500 Pearl

ONLY \$12.25

\author{
1/2 ACRE COLLECTION \\ 2000 Premier \\ 1000 Cooper \\ 1000 Pearl
}

ONLY $\$ 22.75$

\section{$\square$ ONE ACRE COLLECTION 4000 Premier 2000 Cooper 2000 Pearl \\ ONLY $\$ 42.50$}

\section{Strawberry Garden Collections}

Why not grow your own big, sweet, delicious Strawberries? Nothing else can give you the pleasure, satisfaction and profit you will find in your own Strawberry garden. The following collections are composed of our very finest varieties, covering a long season, berries large and extra fine in quality, flavor and appearance.

25 Mastodon

$\square$ IDEAL GARDEN

25 Premier

25 Cooper

25 Pearl

25 Dr. Burrill

ONLY $\$ 2.65$

口 BUNGALOW GARDEN
25 Mastodon
50 Premier
50 Pearl
50 Dr. Burrill
50 Cooper
$\quad$ ONLY $\$ 3.50$

ONLY $\$ 3.50$

\author{
SUBURBAN GARDEN \\ 100 Premier \\ 100 Cooper \\ 100 Pearl \\ 100 Gibson \\ 100 Dr. Burrill \\ ONLY $\$ 4.35$
}

\section{Fruit Tree Collections at Special Low Prices}

Why not make up your mind right now to assure yourself and family a bountiful supply of fruit in the coming years? Along next Summer and Fall when you see your neighbor's trees loaded with fruit you will think how lucky he is and then curse your own misfortune for not having the same. There is no luck about it-just do it yourself and you will never have a better chance than right now because we are offering you some fine trees and at a mighty low price.

\section{$\square$ APPLE TREE BARGAIN}

3 Delicious

2 Early Harvest

2 Grimes Golden

3 Jonathan

3 to $4 \mathrm{ft}$., $\$ 2.55$

4 to $6 \mathrm{ft}$., $\$ 3.65$

\section{PEACH TREE BARGAIN}

3 Elberta

2 Rochester

2 Belle of Georgia

3 J. H. Hale

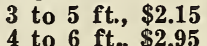

\section{ASSORTED BARGAIN}

2 Abundance Plum

2 Bartlett Pear

2 B. Tartarian Cherry

2 Montmorency Cherry

3 to $4 \mathrm{ft}$., $\$ 3.15$

4 to $6 \mathrm{ft}$., $\$ 4.25$

\section{When Ordering Above Bargains Fill in Here}

For the enclosed remittance, $\$$ checked (X) above:

please send me the special bargains

My Name

Post Office

State. 


\section{Instructions for Ordering}

WHEN TO ORDER. The sooner the better and as a special inducement to have you send in your order early we allow a discount of 7 per cent on orders received during January, 5 per cent on orders received during February and 2 per cent on orders received during March. This discount applies only when cash in full accompanies the order. It is to our mutual advantage when you order early, as it relieves us of office work during the rush season, and as our stock is complete you are certain to find what you want.

HOIV TO ORDER. Use order blank, and be sure to fill this in correctly. We are anxious to give you prompt, efficient service and you can aid us greatly in doing this if you will write your name and address carefully and give the other information called for.

FIGURE PRICES CORRECTLY. For instance, if you order 100 strawberry plants of three different varieties, 300 plants in all, you must figure them at the 100 rate and not at the 300 rate. Or if you order ten fruit trees of ten different varietles you must figure them at the each rate and not at the ten rate. This will save delay and unnecessary correspondence.

HOW TO SEND MONEY. Our terms are cash, or when orders amount to $\$ 10.00$ or more we will book the order with a cash payment of one-fourth the amount and balance can be sent any time before shipment. Remittance may be made by check, bank draft postal or express money orders or cash in rogistered letters. We acknowledge orders the same day they are received.
PARCEL POST SHIPIIENTS. See catalog page 26 for full particulars regarding parcel post shipments.

OU SHIPPING SEASON. Owing to our Ideal soil and location, we can make shipment usually a week sooner than other Michigan growers, usually beginning about March 20th, and continuing until June. In the Fall our stock is fully matured by October 1st and we can ship during October and November. PROMPT SERVICE-QUICK DELIVERY. We are equipped to handle hundreds of orders every twentyfour hours and as we are only 70 miles from Chicago, where quick transfer is made to all railway lines east, west and south, you are assured prompt service and delivery when you deal with us.

No CHAYGE FOR PACKING. We make no charge for wrapping and packing. which is done in the best possible manner by trusted men of long experience. Plenty of damp moss is used so that the stock will reach you in perfect growing condition.

ALL STOCK TRUE TO NAIE. As our stock is all labeled when dug it is practioaily an impossibility to send you stock that is not true to name. However, should such a mistake occur we will replace same free of charge or refund your money. Your order is accepted with the understanding that in no case will we be held liable for more than the original purchase price.

IN CASE OF ERROR OR SHORTAGE notify us immediately, as we are not satisfied until you are. As soon as you recelve your order, check it over, and if not correct, notify us immediately, advising number of packages or crates received.
of

\section{Parcel Post Shipments}

For orders weighing less than 50 pounds we recommend parcel pnst, as it is the safest, quickest and most economical method of shipment. If you reside on a rural route the plants will be delivered to your door; this will avoid delay in planting. We make no extra charge for wrapping or packing parcel post or express shipments. You order your stock at prices quoted in this catalog and when stock arrives

\section{Pay Mail Carrier or Postmaster Parcel Post Charges}

IT IS CHEAPER for you to pay the parcel post charges when you recelve the goods, because when you pay a flat rate for postage you usually pay much more than the actual cost, as it is impossible to accurately estimate the welght of fruit plants or other nursery stoci.

IT IS SAFER because packages that are sent C. O. D. for the charges are given preference by postal clerks and will be delivered promptly and in the best possible condition.

IT IS EASIER for you to order because by the old method it was necessary for you to find out which zone you were in to know how much to include for postage. By this method you remit only the price of the plants, and when they arrive your postmaster or mail carrier tells you the cost of postage.

\section{Emlong's Prices and Complete Variety List of Fruit Trees}

IMPORIANT NOTICE Figure prices correctly. For instance, if you order ten trees of $t$ „n different at the each rate and not at the ten rate. Figure ten to forty trees of one variety at the ten rate and more than forty at the hundred rate.

PEACH TREES

1 year, 3 to $5 \mathrm{ft}$.

Each

1 year, 5 to $6 \mathrm{ft}$

10

$\$ 2.25$

100

$\$ 20.00$

J. H. Hale, Mayflower, Carnan, Fitzgerald, Belle of Georgia, Yellow St. John, Wilma, Crawford's Early, Crawford's Late, Greensboro, Lemon Free.

SOUTH HAVEN PEACH Each $10 \quad 50$

1 year, 3 to $5 \mathrm{ft}$. trees ..... \$0.50 $\$ 4.50 \$ 21.00$

2 year, 5 to $6 \mathrm{ft}$. trees $\ldots . . .6 \quad .75 \quad 7.00 \quad 32.50$

Famous new Peach, better than Elberta, and ripens 14 to 20 days earlier. Bears young, and the hardiest Peach of all.

APPLE TREES

Each

10

100

1 year, 3 to $5 \mathrm{ft}$.

$\$ 0.30$

$\$ 25.00$

2 year, 5 to $6 \mathrm{ft} . \ldots \ldots \ldots \ldots \ldots .45 \quad 4.00$

35.00

SUMMER VARIETLES: Duchess, Early Harvest, Yellow Transparent.

FALI VARHETIES: Wealthy, Stayman Winesap, Grimes Golden.

WINTER VARIETIES: Delicious, Jonathan, York Imperial, Mclntosh, Greening, Rome Beauty, Ben Davis, Baldwin, Northern Spy, Winter Banana.

CRAB APPLES: Hyslop, Transcendent.
CHERRY TREES Each 10

1 year, 3 to $4 \mathrm{ft}$. ........ $\$ 0.40 \$ 3.85$

2 year, 4 to $6 \mathrm{ft}$.

$.60 \quad 5.50$

100

Schmidt, Windsor, Bing, Black Tartarian, Napoleon.

SOUR VARIETIES: Montmorency, Early Richmond.

PEAR TREES Each $10 \quad 100$

1 year, 3 to $4 \mathrm{ft} . \ldots \ldots \ldots \ldots . \$ 0.40 \quad \$ 3.85 \quad \$ 35.00$

2 year, 4 to 6 ft. $\ldots \ldots \ldots \ldots \ldots .60 \quad \mathbf{5 . 5 0} \quad \mathbf{5 0 . 0 0}$

VARIETIES: Bartlett, Kieffer, Seckel, Clapp's Favorite, Sheldon, Duchess, Bosc.

\begin{tabular}{|c|c|c|c|}
\hline LUM TR & $\mathrm{Xa}$ & 10 & 100 \\
\hline $\begin{array}{l}\mathrm{r}, 3 \text { to } 4 \mathrm{f} \\
\mathrm{r}, 4 \text { to } 6 \mathrm{f}\end{array}$ & & $\begin{array}{r}\$ 3.85 \\
\mathbf{5 . 5 0}\end{array}$ & \\
\hline
\end{tabular}

VARIETIES: Abundance, German Prune, Burbank, Monarch, Yellow Egg, Green Gage, Shropshire Damson.

ORANGE QUINCE. 2 year, 4 to $6 \mathrm{ft}$. trees, $75 \mathrm{c}$ each; 10 for $\$ 7.00$.

SUPERB APRICOT. 2 year, 4 to $6 \mathrm{ft}$. trees, 60c each; 10 for $\$ 5.00$. 


\section{Henry Emlong \& Sons, Stevensville, Mich. 111 \\ Date}

Enclosed find \$__for which send me the goods named in this order My Name

Post Office

State

R. F. D. No.

Street and No.

If by Express, ship to

County

Shipping Date

(Town for Express)

Ship by

(Express or Mail)

MIPOR'TAN' $\boldsymbol{T}$. When ordering late in the season, please state whether we shall substitute something as good or better than varieties ordered or return money for any stock we may be out of. Shall we substitute (Yes or No)

When Ordering Trees or Shrubs State Size or Grade Wanted.

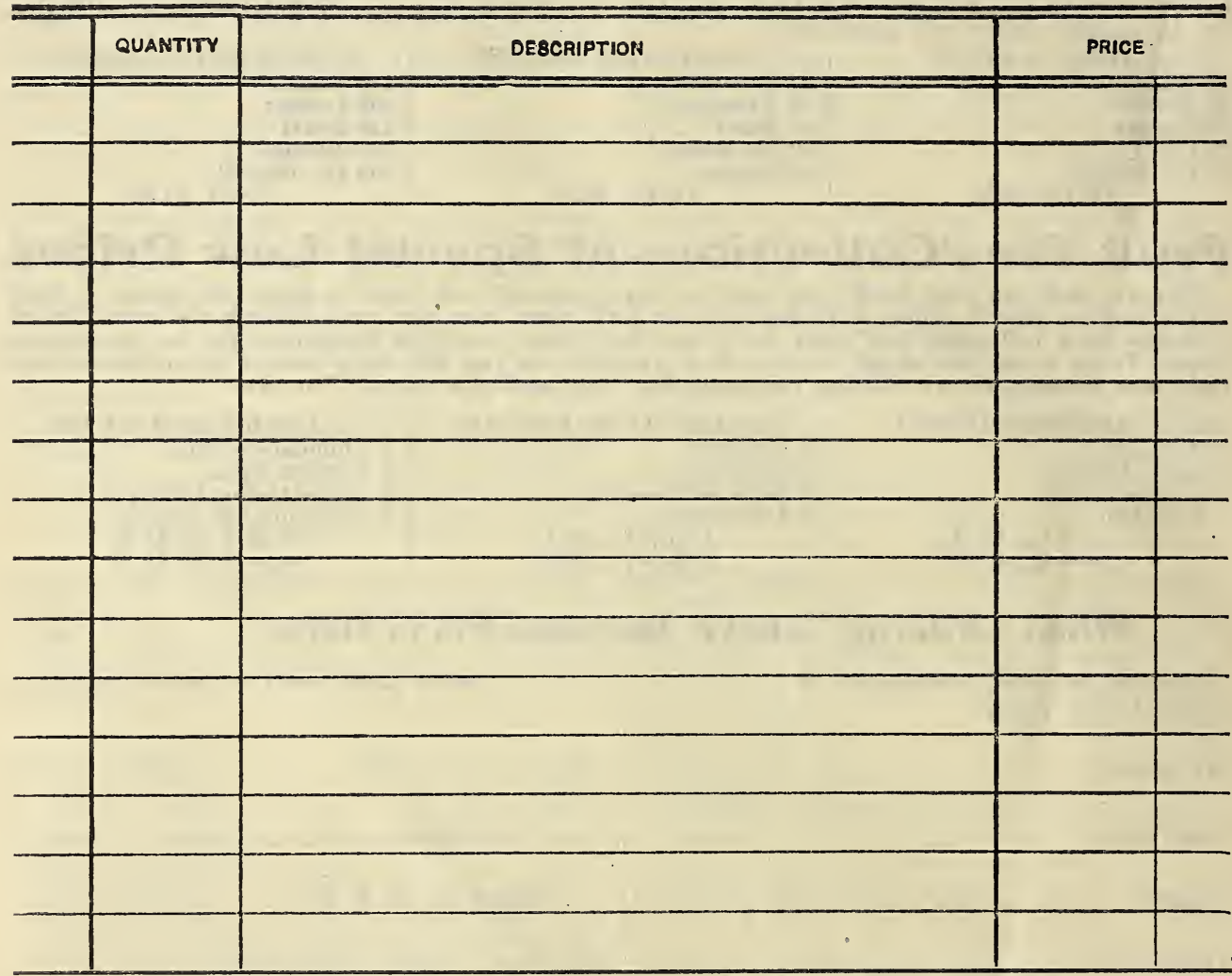

